\title{
Analisa Perbandingan Metode Topsis, SAW dan WP Melalui Uji Sensitifitas Supplier Terbaik
}

\author{
Wina Yusnaeni ${ }^{1}$, Rahayu Ningsih ${ }^{2}$ \\ ${ }^{1}$ Universitas Bina Sarana Informatika \\ Email: wina.wyi@bsi.ac.id \\ ${ }^{2}$ Universitas Bina Sarana Informatika \\ Email: rahayu.ryh@bsi.ac.id
}

\begin{abstract}
Abstrak
Pemilihan suplier yang baik dalam penyediaan bahan baku produksi adalah salah satu faktor yang penting dalam sebuah produksi di perusahaan. Banyak hal yang harus diperhatikan dalam pemilihan suplier bahan baku, karena bahan baku yang di sediakan harus memiliki kualitas yang baik dan sebanding dengan nilai ekonomi yang dikeluarkan oleh perusahaan. PT. Tiga Sekawan Perkasa adalah sebuah perusahaan manufaktur yang melakukan pengolahan bahan baku mentah menjadi bahan jadi, oleh karena itu perusahaan membutuhkan suplier yang baik sehingga bisa menyuplai kebutuhan bahan baku yang memiliki kualitas yang baik, dengan sistem pengiriman yang fleksibel dan harga yang bersaing. Maka dibutuhkan sebuah sistem pemilihan keputusan untuk mendapatkan suplier bahan baku oli yang sesuai dengan kebutuhan perusahaan sehingga bisa menjuang jalannya produksi dengan baik. Kriteria yang telah di tentukan oleh perusahaan dalam pemilihan bahan baku adalah harga, pengiriman, volume dan memiliki kualitas yang baik. Metode yang dipergunakan adalah TOPSIS, SAW, WP dan Perhitungan Uji Sensifitas untuk melihat mana yang lebih relevan dengan studi kasus yang di bahas oleh penulis dalam menentukan suplier yang baik. Dari hasil pengujian metode yang dipergunakan dari tiga metode TOPSIS, SAW dan WP menghasilkan hasil yang berbeda Penggunaan uji sensitifitas menghasilkan metode yang sesuai dengan studi kasus ini yaitu metode topsis. Dengan nilai perubahan TOPSIS sebesar 1,59\%, SAW Sebesar $1 \%$ dan WP sebesar $0,288 \%$.
\end{abstract}

Kata Kunci: PemilihanSuplier, bahan baku, Uji Sensifitas

\begin{abstract}
The selection of a good supplier in the provision of raw material production is one of the factors that are important in a production at the company. A lot of things that must be considered in the selection of suppliers of raw materials, because the raw materials supplied must have good quality and is comparable with the economic value issued by the company..PT. Tiga Sekawan Perkasais a manufacturing company that does the processing of the raw materials raw materials so therefore companies need a good supplier so it could supply the raw material needs to have good quality, with the system flexible delivery and competitive price. Then it takes a decision of the electoral system to get the raw material supplier of oil to suit the needs of the company so that it could menjuang the course of the production well.Criteria specified by the company in the selection of raw materials is the price, delivery, volume and has a good quality. The method used is the TOPSIS, SAW, WP and calculation of Sensifitas Test to see which is more relevant to the case study discussed by the author in determining a good supplier.From the results of the testing method used of the three, SAW and TOPSIS method WP yield different results the use of sensitivity testing generates methods that correspond to this case study method topsis. Value of changes of TOPSIS $1.59 \%$, SAW a $1 \%$ and $0.288 \%$ of $W P$.
\end{abstract}

Keywords: the selection of supplier, Raw Materials, test sensitivity

1. Pendahuluan

$\mathrm{Di}$ era globalisasi seperti saat ini, persaingan antar perusahaan menjadi semakin ketat, Konsumen tidak lagi hanya menginginkan produk yang berkualitas, melainkan juga menuntut pelayanan yang 
baik dan tepat waktu dan Supplier sebagai pihak penyedia bahan baku, sangat berperan penting dalam menentukan kualitas produk dan kelancaran proses produksi (Sulistiana \& Yuliawati, 2012). Untuk menjaga agar persediaan bahan baku tetap optimal, jadwal pembelian bahan baku dan hubungan kerjasama yang baik dengan pihak supplier perlu diperhatikan dan Pemilihan supplier yang efektif dapat membantu perusahaan mencapai hasil produksi yang diinginkan(Taufik, Sumantri, \& Farela, 2014).Berdasarkan catatan Kemenperin, investasi sektor industri manufaktur sepanjang kuartal I tahun 2018 mencapai Rp 62,7 triliun (kompas). Industri pengolahan mencatatkan pertumbuhan pada sebesar $4,5 \%$ pada kuartal 1/2018, lebih tinggi dibanding periode yang sama tahun sebelumnya di angka 4,28\%. Sektor manufaktur masih memberikan kontribusi terbesar dengan mencapai 20,27\% terhadap perekonomian nasional (Pitoko, 2018). Salah satu industri manufaktur yang mengolah bahan baku mentah menjadi minyak pelumas adalah PT. Tiga Sekawan dimana hasil olahan bahan baku akan dikirim ke beberapa perusahaan yang bekerjasama dengan PT. Tiga Sekawan Sejahtera dalam dan luar negeri. Bahan baku mentah yang digunakan yaitu bahan baku oli yang nantinya akan diolah menjadi minyak pelumas. Dan dalam pengadaan bahan baku PT. Tiga Sekawan Sejahtera bekerja sama dengan beberapa supplier. Dalam kurun waktu tiga tahun terakhir PT. Tiga Sekawan Sejahtera mengalami kerugian dikarenakan bahan baku yang dikirimkan tidak sesuai kualitasnya dan bahan baku dikembalikan untuk di kirim ulang sesuai kualitas yang baik hal ini menyebabkan waktu yang lebih panjang dalam proses produksi. Supplier yang bekerjasama dengan PT.Tiga Sekawan Sejahtera ada Empat supplier dimana pemilihan yang dilakukan dengan sistem siapa yang terlebih dahulu melakukan presentasi atau menawarkan bahan baku terlebih dahulu. Hal ini menyebabkan penurunan produksi karena keterlambatan waktu produksi yang menjadi lebih lama. Penilaian pemilihan bukan didasarkan pada kualitas bahan baku yang ditawarkan. Supplier yang terpilih pun sering terjadi permasalahan-permasalahan yaitu kualitas, kuantitas, dan waktu pengiriman yang tidak sesuai dengan yang dijanjikan saat pemesanan sehingga mengganggu dalam proses produksi(Taufik et al., 2014).

Tujuan dari melakukan penelitian ini untuk melakukan pemilihan supplier dengan kriteria yang telah ditentukan dan penilaian bukan semata-mata kepada pemilihan siapa cepat melakukan negosiasi tetapi dilihat dari standarisasi kualitas dan kuantitas bahan baku yang ditawarkan. Dengan mencoba menggunakan tiga metode yaitu TOPSIS, SAW dan WP serta Uji Sensitifitas untuk menentukan metode yang relevan atau sesuai dengan studi kasus ini.

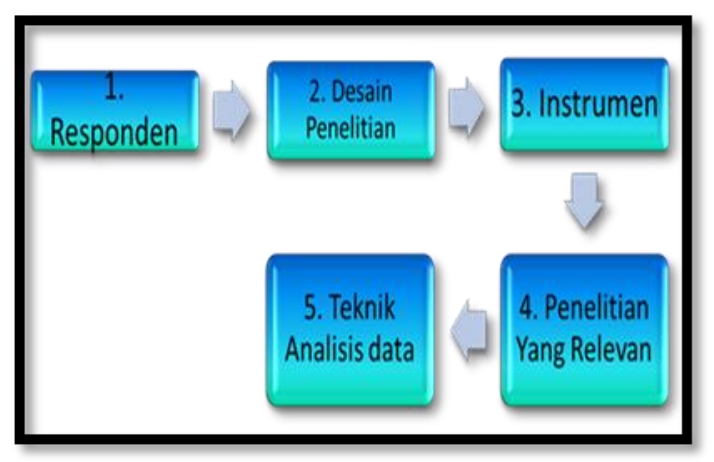

Gambar 1. Metode Penelitian

\section{Metode Penelitian}

\subsection{Responden}

Responden disini adalah tim penilai yang menilai Alternative (supplier) terbaik ang terdiri dari : Direktur, Manager 1, Supervisor 1, dan Supervisor 2. Alternative atau yang diniai disini adalah supplier terpilih yang terdiri dari 5 (Lima) Supplier, Mulai dari Supplier 1- Supplier 5.

\subsection{Desain Penelitian}

tahapan yang dilakukan dalam melakukan penilaian supplier bahan baku yaitu:

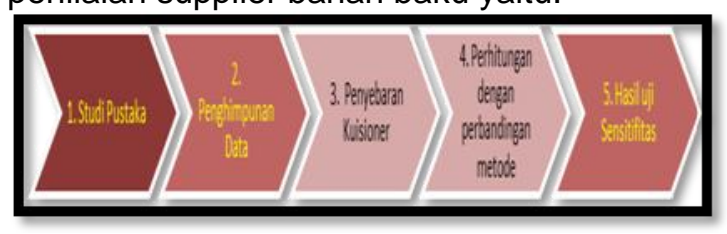

Gambar 2. Tahap desain Penelitian

a) Studi Pustaka

Tahap ini dilakukan untuk mendapatkan informasi berupa referensi teori, penelitian yang relevan dengan metode Topsis, SAW dan WP. 
b) Penghimpunan data

Terdiri dari dua data:
1) Penentuan responden yang dianggap paham akan permasalahan yang ada dan juga merupakan pengambil keputusan.

2) Penentuan Kriteria dan pembuatan kuisioner yang berisi penialaian Alternative terhadap kriteria .

3) Penyebaran Kuisioner

Penyebaran kuisioner ke responden untuk dilakukan penilaian terhadap alternative berdasarkan kriteria, bobot kriteria dan bobot kriteria terhadap alternative.

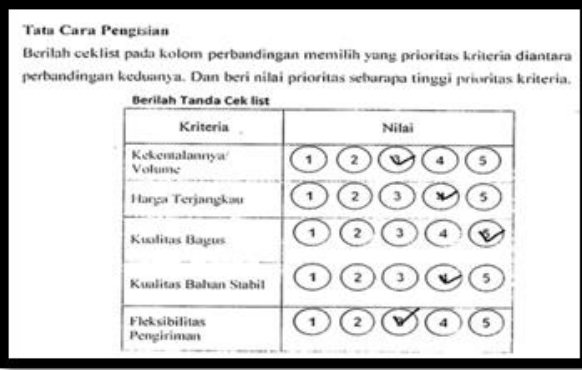

Gambar 3. Kuisioner Perbandingan Kriteria

4) Perhitungan dengan perbandingan metode

Hasil data yang didapat akan di lakukan perhitungan dengan tiga metode yang digunakan yaitu metode topsis, saw dan metode WP.

5) Hasil uji Sensitifitas

Data hasil perhitungan dengan tiga metode kemudian dilakukan pengujian sensitiftas dengan perhitungan penambahan bobot setiap bobot kriteria , dimana hasil dari perhitungan ini akan didapat hasil metode mana yang sesuai

\subsection{Instrumen} dengan studi kasus ini.

Untuk melakukan penilaian dengan kuisioner dilakukan oleh responden untuk melakukan penilaian perbandingan kriteria dan supplier terhadap kriteria.

Tabel 1. Kriteria yang digunakan

\begin{tabular}{cl}
\hline No & \multicolumn{1}{c}{ Kriteria } \\
\hline 1 & Kekentalannya/volume \\
2 & Harga terjangkau
\end{tabular}

3 Kualitas bagus

$4 \quad$ Kulitas bahan stabil

5 Fleksibilitas pengiriman

Sumber : PT. Tiga Sekawan Sejahtera

\subsection{Teknis Analisis Data}

WP (Nofriansyah, 2015):

1) Penjabaran Kriteria, Alternative dan tingkat kepentingan

2) Menentukan Rangking Kriteria

3) Membuat Matrik Kriteria dan alternative

\section{TOPSIS:}

4) Menghitung matriks keputusan yang ternormalisasi

$r i j=\frac{x i j}{\sqrt{\sum_{i=1}^{m} x_{i j}^{2}}}$

Dengan $\mathrm{i}=1,2,3$. .

$\mathrm{j}=1,2,3$. ..m

5) Menghitung matriks keputusan ternormalisasi terbobot

$$
y_{i j}=w_{i} r_{i j}
$$

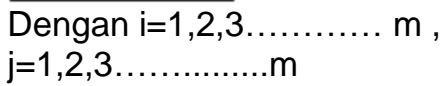

6) Menghitung matriks solusi ideal positif \& matriks solusi ideal negatif Menentukan Matrik Solusi Ideal Positif $\mathrm{A}^{+}$:

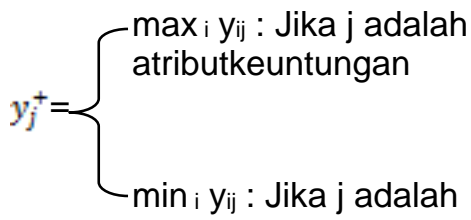

atribut biaya

Menentukan Matrik Solusi Ideal Positif $A^{-}$:

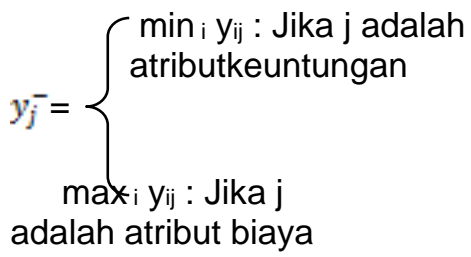

7) Menghitung jarak antara nilai setiap alternatif dengan matriks solusi ideal posisitf dan matriks ideal negatif.

$$
D_{i}^{+}=\sqrt{\sum_{j=1}^{n}\left(y_{i}^{+}-y_{i j}\right)^{2}}
$$


Dengan $\mathrm{i}=1,2,3 \ldots \ldots \mathrm{m}, \mathrm{j}=$
$D_{\mathrm{i}}^{-}=\sqrt{\sum_{j=1}^{n}\left(y_{i j}-y_{i}^{-}\right)^{2}}$

Dengan $\mathrm{i}=1,2,3 \ldots \mathrm{m}, \mathrm{j}=1,2,3 \ldots \ldots . \mathrm{m}$

8) Menentukan nilai preferensi untuk setiap alternatif

$$
V_{\mathrm{i}}=\frac{\mathrm{D}_{\mathrm{i}}^{+}}{\mathrm{D}_{\mathrm{i}}^{-}+\mathrm{D}_{\mathrm{i}}^{+}}
$$

SAW:

$r_{i j}=\left\{\begin{array}{l}\frac{X_{\mathrm{i} j}}{\operatorname{Max} X_{\mathrm{i} j}} \text { Jika J Atribut Keuntungan (Benefit) } \\ \frac{\operatorname{Min}_{\mathrm{i}} X_{\mathrm{i} j}}{X_{\mathrm{i} j}} \text { JikaJ Atribut Biaya (Cost) }\end{array}\right.$

Dimana:

rij = Nilai Rating Kinerja Ternormalisasi

$\mathrm{xij}=$ nilai atribut yang dimiliki dari setiap

kriteria

MaxiXij = Nilai Terbesar dari setiap kriteria

MiniXij = Nilai terkecil dari setiap kriteria

Benefit $=$ jika nilai terbesar adalah terbaik

Cost $=$ Jika nilai terkecil adalah terbaik

$\mathrm{i}=1,2, . . \mathrm{m}$ dan $\mathrm{j}=1,2, \ldots \mathrm{n}$. Nilai preferensi untuk setiap alternatif ( ) diberikan.

5) Melakukan Proses Kriteria

Perangkingan

$$
\sum_{j=1}^{n} W_{j} r_{i j}
$$

Nilai yang lebih besar mengindikasikan bahwa alternatif lebih terpilih

WP:

4) Mencari Preferensi Alternative (S)

$$
S i=\prod_{j=1}^{n} X_{i j}^{w j}
$$

Dengan $\mathrm{i}=1,2, . . \mathrm{m}$; dimana $\Sigma=1$ adalah pangkat bernilai positif untuk keuntungan dan bernilai negatif untuk atribut biaya.

$w_{j}=\frac{w_{i}}{\sum w_{j}}$

5) Mencari Nilai Preferensi Alternative(V)

$$
\begin{aligned}
& v_{i}=\frac{\Pi_{j=1}^{n} x_{i j}^{w j}}{\prod_{j=1}^{n}\left(x_{i}^{*}\right)^{w j}} \ldots \ldots \ldots . . . \quad \text { dengan } \\
& \mathrm{i}=1,2, \ldots \ldots . \mathrm{m}
\end{aligned}
$$

Untuk kriterianya terbagi dalam dua kategori yaitu bernilai positif termasuk dalam kriteria keuntungan (benefit) dan yang bernilai negatif termasuk dalam kriteria biaya (cost).

\subsection{Penelitian Yang Relevan}

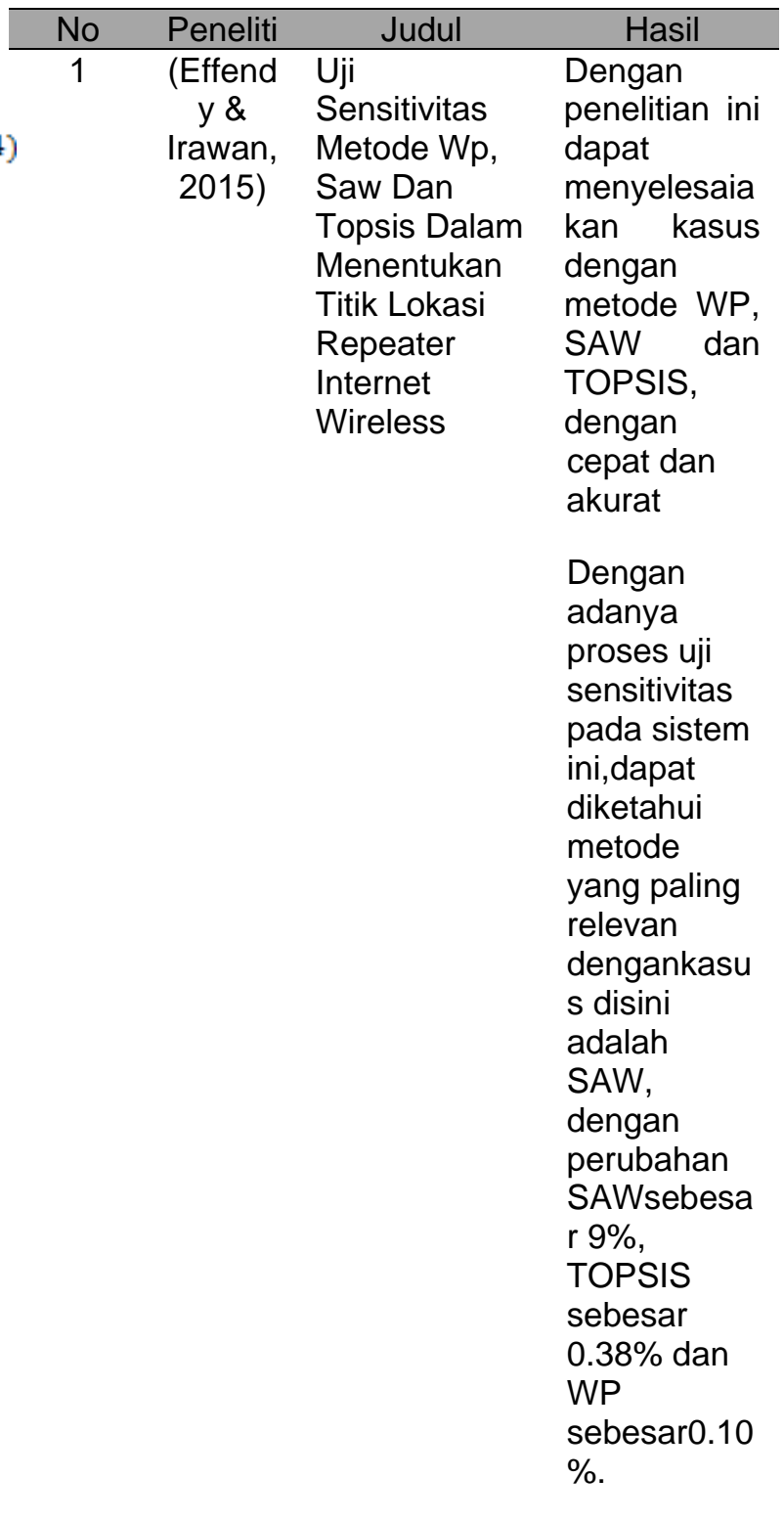




\begin{tabular}{|c|c|c|c|c|c|c|c|}
\hline \multirow[t]{2}{*}{2} & \multirow[t]{2}{*}{$\begin{array}{c}\text { (Riman } \\
\text { tho \& } \\
\text { Cahya } \\
\text { di, } \\
2017)\end{array}$} & \multirow[t]{2}{*}{$\begin{array}{l}\text { Pemilihan } \\
\text { Supplier } \\
\text { Rubber Parts } \\
\text { Dengan } \\
\text { Metode } \\
\text { Analytical } \\
\text { Hierarchy } \\
\text { Process Di } \\
\text { PT.XYZ }\end{array}$} & \multirow{2}{*}{$\begin{array}{l}\text { Dalam } \\
\text { pemilihan } \\
\text { supplier } \\
\text { sebaiknya } \\
\text { dilakukan } \\
\text { keterlibatan } \\
\text { beberapa } \\
\text { bagian } \\
\text { terkait tidak } \\
\text { hanya } \\
\text { bagian } \\
\text { purchasing, } \\
\text { seperti } \\
\text { bagian } \\
\text { enginering, } \\
\text { quality dan } \\
\text { produksi. }\end{array}$} & & & & $\begin{array}{l}\text { Utama } \\
\text { mempunyai } \\
\text { nilai bobot } \\
0,38 \text { paling } \\
\text { tinggi } \\
\text { dibandingka } \\
\text { n kedua } \\
\text { supplier } \\
\text { yang lain. }\end{array}$ \\
\hline & & & & 4 & $\begin{array}{l}\text { (Ngata } \\
\text { wi \& } \\
\text { Setyani } \\
\text { ngsih, } \\
2011)\end{array}$ & $\begin{array}{l}\text { Analisis } \\
\text { Pemilihan } \\
\text { Supplier } \\
\text { Menggunaka } \\
\mathrm{n} \\
\text { Metode } \\
\text { Analytic } \\
\text { Hierarchy }\end{array}$ & $\begin{array}{l}\text { Berdasarka } \\
\mathrm{n} \\
\text { pengolahan } \\
\text { dan analisis } \\
\text { data yang } \\
\text { telah } \\
\text { dilakukan } \\
\text { pada bagian }\end{array}$ \\
\hline 3 & $\begin{array}{l}\text { (Sulisti } \\
\text { ana \& } \\
\text { Yuliaw } \\
\text { ati, } \\
\text { 2012) }\end{array}$ & $\begin{array}{l}\text { Analisis } \\
\text { Pemilihan } \\
\text { Supplier } \\
\text { Bahan Baku } \\
\text { Dengan } \\
\text { Menggunaka } \\
n \\
\text { Metode } \\
\text { Fuzzy } \\
\text { Analytical } \\
\text { Hierarchy } \\
\text { Process } \\
\text { (Fahp) }\end{array}$ & $\begin{array}{l}\text { Kriteria } \\
\text { yang } \\
\text { dijadikan } \\
\text { dasar } \\
\text { penilaian } \\
\text { dalam } \\
\text { pemilihan } \\
\text { supplier PT. } \\
\text { Mitra } \\
\text { Mandiri } \\
\text { Perkasa } \\
\text { terdiri dari } \\
\text { kualitas } \\
\text { barang, } \\
\text { harga } \\
\text { barang, } \\
\text { pengiriman } \\
\text { barang, } \\
\text { garansi dan } \\
\text { layanan } \\
\text { pengaduan, } \\
\text { dan } \\
\text { kapasitas } \\
\text { dan fasilitas } \\
\text { produksi.Be } \\
\text { rdasarkan } \\
\text { hasil } \\
\text { pembobotan } \\
\text { yang }\end{array}$ & & & $\begin{array}{l}\text { Process } \\
\text { (Ahp) }\end{array}$ & $\begin{array}{l}\text { sebelumnya } \\
\text { maka } \\
\text { kesimpulan } \\
\text { yang dapat } \\
\text { diambil } \\
\text { adalah } \\
\text { menetapkan } \\
\text { supplier "A" } \\
\text { sebagai } \\
\text { supplier } \\
\text { yang } \\
\text { terbaik. Hal } \\
\text { tersebut } \\
\text { bisa } \\
\text { diketahui } \\
\text { dengan } \\
\text { adanya nilai } \\
\text { akhir } \\
\text { tertinggi } \\
\text { pada } \\
\text { perhitungan } \\
\text { akhir AHP } \\
\text { yaitu } \\
\text { dengan nilai } \\
\text { sebesar } \\
0.240 \text {. }\end{array}$ \\
\hline & & & $\begin{array}{l}\text { dengan } \\
\text { metode } \\
\text { Fuzzy } \\
\text { Analytical } \\
\text { Hierarchy } \\
\text { Process } \\
\text { (FAHP), PT. } \\
\text { Aneka } \\
\text { Lokanusa }\end{array}$ & & & & \\
\hline
\end{tabular}




\begin{tabular}{ll}
\hline (Merry & Pemilihan \\
Gintin & Supplier \\
g, \& & Buah Dengan \\
Marpa & Pendekatan \\
ung, & Metode \\
2013) & Analytical \\
& Hierarchy \\
& Process \\
& (AHP) Dan \\
& Topsis: Studi \\
& Kasus Pada \\
& Perusahaan \\
& Retail
\end{tabular}

Adapun
evaluasi
supplier
dengan
metode
TOPSIS
menghasilk
an supplier
terbaik
adalah
alternatif A,
selanjutnya
berturut-
turut
alternatif C,
alternatif D,
dan
alternatif B.

Kontribusi

penelitian

dengan

metode

AHP dan

TOPSIS ini

dapat

membantu

PT Hero

Supermarke

t, Tbk dalam memilih dan mengevalua si supplier buah sesuai dengan kriteria utama disamping kriteria lain yang bisa menjadi bahan pertimbanga $\mathrm{n}$ dalam menentukan supplier.

\section{Hasil dan Pembahasan}

3.1. Tahapan Perhitungan TOPSIS, SAW dan WP

Penjabaran kriteria, alternative dan tingkat kepentingan :

Tingkat Kepentingan dengan Nilai Bobot:

1 = Sangat rendah

2 = Rendah

3 = Cukup

4 = Tinggi
$5=$ Sangat Tinggi

Tabel 3.1 Bobot Kriteria dan penggolongan

\begin{tabular}{clcl}
\hline No & \multicolumn{1}{c}{ Kriteria } & $\begin{array}{c}\text { Bob } \\
\text { ot }\end{array}$ & $\begin{array}{c}\text { Penggolon } \\
\text { gan }\end{array}$ \\
\hline 1 & $\begin{array}{l}\text { Kekentalannya/vol } \\
\text { ume }\end{array}$ & & Benefit \\
2 & $\begin{array}{l}\text { Harga terjangkau } \\
\text { Kualitas bagus }\end{array}$ & 4 & $\begin{array}{l}\text { Cost } \\
3\end{array}$ \\
4 & $\begin{array}{l}\text { Kualitas bahan } \\
\text { stabil }\end{array}$ & 4 & $\begin{array}{l}\text { Benefit } \\
\text { Benefit }\end{array}$ \\
5 & $\begin{array}{l}\text { Fleksibilitas } \\
\text { pengiriman }\end{array}$ & 4 & Benefit \\
\hline
\end{tabular}

Sumber : PT. Tiga Sekawan dan

Penelitian

Tabel 3.2. Tim Penilai

\begin{tabular}{cl}
\hline No & Jabatan \\
\hline 1 & Direktur \\
\hline 2 & Manager \\
\hline 3 & Supervisor \\
\hline 4 & Supervisor \\
\hline
\end{tabular}

Sumber : PT. Tiga Sekawan dan Penelitian

Alternative yang digunakan dimana disini adalah supplier:

Tabel 3.3 Alternative

\begin{tabular}{cc} 
No & Kode Supplier \\
\hline 1 & SUP1 \\
\hline 2 & SUP2 \\
\hline 3 & SUP3 \\
\hline 4 & SUP4
\end{tabular}

Sumber : Penelitian

Nilai Bobot Kriteria dan Supplier hasil penilaian tim penilai :

Tabel 3.4 Tabel Hasil Perbandingan

Supplier (Alternative terhadap Kriteria)

\begin{tabular}{cccccc}
\hline & KR1 & KR2 & KR3 & KR4 & KR5 \\
\hline SUP1 & 3 & 4 & 4 & 4 & 3 \\
\hline SUP2 & 4 & 4 & 4 & 4 & 4 \\
\hline SUP3 & 4 & 3 & 3 & 3 & 3 \\
\hline SUP4 & 3 & 3 & 3 & 3 & 3
\end{tabular}

Sumber : PT. Tiga Sekawan dan Penelitian

Hasil perhitungan dengan tiga metode:

Tabel 3.5 Tabel Hasil Perhitungan dengan metode Topsis, SAW dan WP

\begin{tabular}{cccc}
\hline $\mathrm{V}$ & TOPSIS & SAW & WP \\
\hline $\mathrm{VI}$ & 0,557039066 & 17 & 0,245939378
\end{tabular}




\begin{tabular}{llll}
\hline V2 & 0,328915795 & 19 & 0,27593295 \\
\hline V3 & 0,557039066 & 17 & 0,245939378 \\
\hline V4 & 0,671084205 & 16 & 0,232188295
\end{tabular}

\section{Sumber : Hasil Perhitungan Penelitian}

Hasil perhitungan diatas didapat perbedaan hasil nilai tertinggi dimana dengan metode topsis didapat nilai tertinggi adalah V4 (Supplier 4), untuk metode SAW nilai tertinggi terdapat di V2 (Supplier 2), dan dnegan metode WP didapat adalah nilai tertinggi adalah V2 (Supplier 2). Dari perbedaan diatas dilakukan uji sensitifitas untuk mengertahui mettode yang sesuai dengan studi kasus ini.

\subsection{Uji Sensitifitas}

uji sensitifitas dilakukan untuk mengetahui dan mendapatkan hasil dari perbandingan ketiga metode dari MADM untuk mengetahui mana yang lebih sensitif suatu metode dalam suatu kasus dalam perubahan rangking di setiap metode.

Perhitungan uji sensitifitas dengan mengggunakan derajat sensitifitas (Sj) di setiap atribut (Yeh, 2002):

1. Menentukan semua bobot atribut, $w j=1$ (nilai awal bobot), dengan $j=1,2, \ldots . n$ (banyaknya atribut).

2. Merubah bobot atribut dalam range 12, dan menaikkan nilai bobot dengan 0,1 , dan yang lainnya tetap bernilai 1 .

3. Normalisasi bobot atribut tersebut dengan cara membentuk nilai bobot sedemikian hingga $\Sigma=1$.

4. Aplikasikan di ketiga metode tersebut (WP, SAW, dan TOPSIS) untuk bobotbobot atribut yang telah dibentuk pada langkah 3.

5. Menghitung prosentase perubahan ranking dengan cara membandingkan seberapa perubahan rangking yang terjadi jika dibandingkan dengan kondisi pada saat bobotnya sama (bobot = 1).

Dari Tabel 3.5 Tambahkan 0.5 di nilai bobot awal, nilai bobot kriteria awal : $(4,4,4,4,4)$ menjadi $(4.5,4,4,4,4)$ dan hasil perhitungan dengan penambahan 0.5 pada bobot kriteria pertama :

Tabel 3.6 Nilai Preferensi Bobot Awal Ditambah 0,5

\begin{tabular}{cccc}
\multicolumn{6}{l}{$\mathbf{W} \mathbf{1 + 0 . 5}$} \\
\hline $\mathrm{V}$ & TOPSIS & SAW & WP \\
\hline $\mathrm{V} 1$ & 0,558604 & 0,17375 & 0,245016 \\
\hline
\end{tabular}

\begin{tabular}{crrc}
\hline V2 & 0,300613 & 0,195 & 0,276882 \\
\hline V3 & 0,4966 & 0,175 & 0,246785 \\
\hline V4 & 0,663344 & 0,16375 & 0,231317 \\
\hline Max & 0,663344 & 0,195 & 0,276882 \\
\hline $\begin{array}{c}\text { Peru } \\
\text { baha } \\
\text { n }\end{array}$ & $-0,774 \%$ & $0,500 \%$ & $0,095 \%$ \\
\hline
\end{tabular}

Sumber : Hasil Perhitungan Penelitian Adanya penambahan pada nilai bobot kriteria pertama sebanyak 0.5 sehingga nilai bobot pertama menjadi 4.5 . duilakukan dengan perhitungan 3 metode dengan persentase dibawah $1 \%$.

Tabel 3.7 Nilai Preferensi Bobot Awal Ditambah 1

\begin{tabular}{crrc}
\multicolumn{6}{l}{$\mathbf{W} \mathbf{1 + 1}=\mathbf{\{ 5 , 4 , 4 , 4 , 4}\}$} \\
\hline $\mathrm{V}$ & TOPSIS & SAW & WP \\
\hline $\mathrm{V} 1$ & 0,577129 & 0,1775 & 0,244094 \\
\hline $\mathrm{V} 2$ & 0,315082 & 0,2 & 0,27783 \\
\hline $\mathrm{V} 3$ & 0,526285 & 0,18 & 0,24763 \\
\hline $\mathrm{V} 4$ & 0,684918 & 0,1675 & 0,230446 \\
\hline Max & 0,684918 & 0,2 & 0,27783 \\
\hline $\begin{array}{c}\text { Perub } \\
\text { ahan }\end{array}$ & $2,157 \%$ & $\begin{array}{c}0,500 \\
\%\end{array}$ & $0,095 \%$ \\
\hline
\end{tabular}

\section{Sumber : Hasil Perhitungan Penelitian}

Penambahan bobot kriteria pertama sebanyak 1 sehingga nilai bobot menjadi 5 dan dilakukan perhitungan kembali dengan 3 metode. Selanjutnya dilakukan hal yang sama untuk bobot kriteria sampai bobot ke 5 dengan penambahan 0.5 dan 1.

Tabel 3.8 Nilai Preferensi Bobot Kedua Ditambah 0,5

$\mathrm{W} 2+0.5$

\begin{tabular}{ccrr}
\hline $\mathrm{V}$ & TOPSIS & \multicolumn{1}{c}{ SAW } & \multicolumn{1}{c}{ WP } \\
\hline $\mathrm{V} 1$ & 0,566964 & 0,17375 & 0,245094 \\
\hline $\mathrm{V} 2$ & 0,355417 & 0,19375 & 0,274984 \\
\hline $\mathrm{V} 3$ & 0,541604 & 0,175 & 0,246863 \\
\hline $\mathrm{V} 4$ & 0,644583 & 0,165 & 0,23306 \\
\hline Max & 0,644583 & 0,19375 & 0,274984 \\
\hline $\begin{array}{c}\text { Perub } \\
\text { ahan }\end{array}$ & $-4,034 \%$ & $-0,63 \%$ & $-0,285 \%$ \\
\hline
\end{tabular}

Sumber : Hasil Perhitungan Penelitian

Tabel 3.9 Nilai Preferensi Bobot Kedua Ditambah 1

\begin{tabular}{ccrc} 
W2+1 & & & \\
\hline $\mathrm{V}$ & TOPSIS & SAW & WP \\
\hline V1 & 0,577129 & 0,1775 & 0,244247 \\
\hline V2 & 0,495014 & 0,1975 & 0,274035 \\
\hline V3 & 0,546634 & 0,18 & 0,247786 \\
\hline V4 & 0,634906 & 0,17 & 0,233932 \\
\hline Max & 0,634906 & 0,1975 & 0,274035 \\
\hline Perub & $-0,968 \%$ & $0,375 \%$ & $-0,095 \%$ \\
\hline
\end{tabular}




\begin{tabular}{cccc}
\hline \multicolumn{3}{l}{$\begin{array}{l}\text { ahan } \\
\text { Sumber : Hasil Perhitungan Penelitian } \\
\text { Tabel 3.10 Nilai Preferensi Bobot Ketiga } \\
\text { Ditambah } \mathbf{0 , 5}\end{array}$} \\
\begin{tabular}{cccc} 
W3+0.5 & & & \\
\hline V & TOPSIS & SAW & WP \\
\hline V1 & 0,541604 & 0,175 & 0,246785 \\
\hline V2 & 0,322126 & 0,195 & 0,276882 \\
\hline V3 & 0,566964 & 0,17375 & 0,245016 \\
\hline V4 & 0,677874 & 0,16375 & 0,231317 \\
\hline Max & 0,677874 & 0,195 & 0,276882 \\
\hline Perub & & & \\
ahan & $4,297 \%$ & $-0,25 \%$ & $0,285 \%$ \\
\hline
\end{tabular}
\end{tabular}

Sumber : Hasil Perhitungan Penelitian

Tabel 3.11 Nilai Preferensi Bobot Ketiga Ditambah 1

W3+1

\begin{tabular}{ccrc}
\hline $\mathrm{V}$ & TOPSIS & \multicolumn{1}{c}{ SAW } & \multicolumn{1}{c}{ WP } \\
\hline $\mathrm{V} 1$ & 0,526285 & 0,18 & 0,24763 \\
\hline $\mathrm{V} 2$ & 0,315082 & 0,2 & 0,27783 \\
\hline $\mathrm{V} 3$ & 0,577129 & 0,1775 & 0,244094 \\
\hline $\mathrm{V} 4$ & 0,684918 & 0,1675 & 0,230446 \\
\hline Max & 0,684918 & 0,2 & 0,27783 \\
\hline $\begin{array}{c}\text { Perub } \\
\text { ahan }\end{array}$ & $0,704 \%$ & 0,500 \\
\hline
\end{tabular}

Sumber : Hasil Perhitungan Penelitian

Tabel 3.12 Nilai Preferensi Bobot Keempat Ditambah 0,5

W4+0.5

\begin{tabular}{ccrr}
\hline $\mathrm{V}$ & TOPSIS & \multicolumn{1}{c}{ SAW } & \multicolumn{1}{c}{ WP } \\
\hline $\mathrm{V} 1$ & 0,526285 & 0,18 & 0,24763 \\
\hline $\mathrm{V} 2$ & 0,315082 & 0,2 & 0,27783 \\
\hline $\mathrm{V} 3$ & 0,577129 & 0,1775 & 0,244094 \\
\hline $\mathrm{V} 4$ & 0,684918 & 0,1675 & 0,230446 \\
\hline Max & 0,684918 & 0,2 & 0,27783 \\
\hline $\begin{array}{c}\text { Perub } \\
\text { ahan }\end{array}$ & $0,704 \%$ & $0,500 \%$ & $0,095 \%$ \\
\hline
\end{tabular}

Sumber : Hasil Perhitungan Penelitian

Tabel 3.13 Nilai Preferensi Bobot Keempat Ditambah 1

\begin{tabular}{ccrc} 
W4+1 & & & \\
\hline $\mathrm{V}$ & TOPSIS & \multicolumn{1}{c}{ SAW } & \multicolumn{1}{l}{ WP } \\
\hline $\mathrm{V} 1$ & 0,526285 & 0,18 & 0,24763 \\
\hline $\mathrm{V} 2$ & 0,315082 & 0,2 & 0,27783 \\
\hline $\mathrm{V} 3$ & 0,577129 & 0,1775 & 0,244094 \\
\hline $\mathrm{V} 4$ & 0,684918 & 0,1675 & 0,230446 \\
\hline Max & 0,684918 & 0,2 & 0,27783 \\
\hline $\begin{array}{c}\text { Perub } \\
\text { ahan }\end{array}$ & $2,157 \%$ & $\begin{array}{c}0,500 \\
\%\end{array}$ & $0,095 \%$ \\
\hline
\end{tabular}

Sumber : Hasil Perhitungan Penelitian
Tabel 3.14 Nilai Preferensi Bobot Kelima Ditambah 0,5

W5+0.5

\begin{tabular}{ccrc}
\hline $\mathrm{V}$ & TOPSIS & \multicolumn{1}{c}{ SAW } & WP \\
\hline $\mathrm{V} 1$ & 0,568502 & 0,17375 & 0,245939 \\
\hline $\mathrm{V} 2$ & 0,321065 & 0,195 & 0,275933 \\
\hline $\mathrm{V} 3$ & 0,568502 & 0,17375 & 0,245939 \\
\hline $\mathrm{V} 4$ & 0,678935 & 0,16375 & 0,232188 \\
\hline Max & 0,678935 & 0,195 & 0,275933 \\
\hline $\begin{array}{c}\text { Perub } \\
\text { ahan }\end{array}$ & $-0,598 \%$ & $-0,50 \%$ & $-0,190 \%$ \\
\hline
\end{tabular}

Sumber : Hasil Perhitungan Penelitian

Tabel 3.14 Nilai Preferensi Bobot Kelima Ditambah 1

W5+1

\begin{tabular}{ccrr}
\hline $\mathrm{V}$ & TOPSIS & \multicolumn{1}{c}{ SAW } & \multicolumn{1}{c}{$\mathrm{WP}$} \\
\hline $\mathrm{V} 1$ & 0,580089 & 0,1775 & 0,24496 \\
\hline $\mathrm{V} 2$ & 0,313015 & 0,2 & 0,278816 \\
\hline $\mathrm{V} 3$ & 0,580089 & 0,1775 & 0,24496 \\
\hline $\mathrm{V} 4$ & 0,686985 & 0,1675 & 0,231264 \\
\hline $\mathrm{Max}$ & 0,686985 & 0,2 & 0,278816 \\
\hline $\begin{array}{c}\text { Perub } \\
\text { ahan }\end{array}$ & $0,805 \%$ & $0,500 \%$ & $0,288 \%$ \\
\hline
\end{tabular}

Sumber : Hasil Perhitungan Penelitian

Jumlah prosentase perubahan ranking dengan metode TOPSIS, SAW dan WP dalam kasus ini.

\begin{tabular}{lccc}
\hline Kriteria & Topsis & SAW & WP \\
\hline $\begin{array}{l}\text { Kriteria 1+ } \\
(0,5)\end{array}$ & $\begin{array}{c}- \\
0,774 \%\end{array}$ & $0,500 \%$ & $0,095 \%$ \\
\hline Kriteria 1+ (1) & $2,157 \%$ & $0,500 \%$ & $0,095 \%$ \\
\hline $\begin{array}{l}\text { Kriteria 2 + } \\
(0,5)\end{array}$ & $\begin{array}{c}- \\
4,034 \%\end{array}$ & $-0,625 \%$ & $-0,285 \%$ \\
\hline $\begin{array}{l}- \\
\text { Kriteria 2 + (1) }\end{array}$ & $0,968 \%$ & $0,375 \%$ & $-0,095 \%$ \\
\hline $\begin{array}{l}\text { Kriteria 3+ } \\
(0,5)\end{array}$ & $4,297 \%$ & $-0,250 \%$ & $0,285 \%$ \\
\hline Kriteria 3+ (1) & $0,704 \%$ & $0,500 \%$ & $0,095 \%$ \\
\hline $\begin{array}{l}\text { Kriteria 4+ } \\
(0,5)\end{array}$ & $-2,16 \%$ & $-0,50 \%$ & $-0,095 \%$ \\
\hline Kriteria 4+(1) & $2,16 \%$ & $0,50 \%$ & $0,095 \%$ \\
\hline $\begin{array}{l}\text { Kriteria 5 + } \\
(0,5)\end{array}$ & $-0,60 \%$ & $-0,50 \%$ & $-0,190 \%$ \\
\hline Kriteria 5 + (1) & $0,81 \%$ & $0,50 \%$ & $0,288 \%$ \\
\hline Jumlah & $1,590 \%$ & $1,000 \%$ & $0,288 \%$ \\
\hline
\end{tabular}

Hasil perubahan nilai hasil perhitungan uji sensitifitas dengan penamabahan bobot kriteria 1 sampai dengan bobot kriteria 5 direkap didapat bahwa nilai perubahan tertinggi terdapat pada metode TOPSIS 
dengan nilai perubahan $1.59 \%$. SAW didapat perubahan dengan nilai perubahan sebesar $1 \%$ dan WP dengan nilai perubahan sebesar $0.28 \%$. oleh karena itu metode yang paling cocok dengan studi kasus ini adalah metode TOPSIS.

\section{Kesimpulan}

Dari hasil Penelitian diatas dapat disimpulkan bahwa:

1. Adanya beberapa kriteria yang mempengaruhi dalam pemilihan supplier yaitu : mulai dari kekentalan, kualitas bagus, harga terjangkau, kualitas bahan stabil dan fleksibilitas pengiriman dengan bobot masingmasing kriteria adalah 4 .

2. Perlunya penilaian dari beberapa pihak yang memang ahli dan mengerti akan kualitas suatu produk bukan hanya satu pihak saja.

3. Pengujian dengan tiga metode TOPSIS, SAW dan WP menghasilkan hasil yang berbeda.

4. Penggunaan uji sensitifitas menghasilkan metode yang sesuai dengan studi kasus ini yaitu metode topsis. Dengan nilai perubahan TOPSIS sebesar 1,59 \%, SAW Sebesar $1 \%$ dan WP sebesar $0,288 \%$.

\section{Referensi}

Effendy, D. A., \& Irawan, R. H. (2015). Uji Sensitivitas metode WP, SAW Dan TOPSIS Dalam Menentukan Titik Lokasi Repeater Internet Wireless. Seminar Nasional Teknologi Informasi Dan Multimedia, 6-8.

Merry, L., Ginting, M., \& Marpaung, B. (2013). Pemilihan Supplier Buah Dengan Pendekatan Metode Analytical Hierarchy Process ( AHP ) Dan TOPSIS: Studi Kasus Pada Perusahaan Retail. Jurnal Teknik Dan Ilmu Komputer, (November 2013), 4858.

Ngatawi, \& Setyaningsih, I. (2011). Analisis Pemilihan Supplier Menggunakan Metode Analytic Hierarchy Process
(Ahp). Jurnal IImiah Teknik Industri, 10(1), 7-13.

Nofriansyah, D. (2015). Konsep Data Mining Sistem Pendukung Keputusan (I). Medan: Deeppublish.

Pitoko, R. A. (2018). Kuartal I 2018, Nilai Investasi Sektor Manufaktur Tembus Rp 62,7 Triliun - Kompas.com. Retrieved August 8, 2018, from https://ekonomi.kompas.com/read/201 8/05/26/141026626/kuartal-i-2018nilai-investasi-sektor-manufakturtembus-rp-627-triliun

Rimantho, D., \& Cahyadi, B. (2017). Pemilihan Supplier Rubber Parts Dengan Metode Analytical Hierarchy Process Di PT . XYZ. Jurnal Rekayasa Sistem \& Industri, 6(2), 93104.

https://doi.org/10.26593/jrsi.v6i2.2094. 93-104

Sulistiana, W., \& Yuliawati, E. (2012). Analisis Pemilihan Supplier Bahan Baku Dengan Metode Fahp. Jurnal Teknik Industri, 12(20). https://doi.org/10.1007/s13398-0140173-7.2

Taufik, R., Sumantri, Y., \& Farela, C. T. (2014). Penerapan Pemilihan Supplier Bahan Baku Ready Mix Berdasarkan Integrasi Metode AHP dan TOPSIS ( Studi Kasus Pada PT Merak Jaya Beton, Malang ). Jurnal Rekayasa Dan Manajemen Sistem Industri, 2(5), 1067-1076.

Yeh, C. (2002). A Problem-based Selection of Multi-attribute Decision-making Methods. Research, International Transaction in Operasional, 9(2), 169181.

https://doi.org/https://doi.org/10.1111/ 1475-3995.00348 